\title{
ADDRESSING THE NEED OF TEACHING ENGLISH FOR SPECIFIC PURPOSE AT SMK KESEHATAN BAKTI ASSYUKUR
}

\author{
Robby Trimaulana ${ }^{1}$, Efransyah $^{2}$ \\ IKIP Siliwangi \\ ${ }^{1}$ Robbytrimaulana7@gmail.com, ${ }^{2}$ efransbae@gmail.com
}

\begin{abstract}
CTL method is one of the teaching techniques where students work in a group. It is used to improve the student's skill in mastering and understanding English vocabulary. This study tries to determine the effectiveness of teaching and learning at the tenth-grade students of Vocational School. The main goal of this research is to improve English language skills, especially in vocabulary understanding. The method of this research is classroom action research and the populations are the tenth-grade students of pharmacy which consist of nine students as sample randomly. The data collection was done by pre-test and post-test as research instruments. The results of this research that had been carried out during the study showed that the post-test average score $(71,5 \%)$ is higher than the pre-test average value $(49,3 \%)$. It shows that the CTL method is very effective in increasing students' understanding of English, especially in the homonym vocabulary pronounciation and spelling words.
\end{abstract}

Keywords: ESP, CTL, Vocabulary, Teaching

\section{INTRODUCTION}

English has become an international language and it is very important for communication in the world. It can affects many aspects of the world, such as a culture, social, politic, and education. Education, which is to improve the ability and skill to gain knowledge about the science era has become the main target of each country. It has been the key to open that era and it requires English. English which is used to communicate in a study place, must be learnt by each student. It is supported by widdoson (1979;120-121) cited in (Simbolon at al, 2019) stated that" English especially speaking is initially the most important". Applying it as a standard of learning in second languages is one of the problems faced by the vocational school at SMK Kesehatan Bakti Assyukur.

As an educational support environment, English especially which conducted in that study programs of ESP grows very slowly. For specific purpose it is a course which concentrates on medical programs. ESP grew up started to in second world war, which cause of science, technology and economic activities was spread on entire world (Hutchinson \& Waters, 1987). It means that the ESP is the which is very important thing in vocational school. The focus and concentration of it's studies program are not suitable and equivalent for students to be learned. It is only as requirement that is needed by all study programs and must be developed according to students' need and also research objectives. In fact, there is not much correlation between the goals from students' needs and teaching learning activity in the class. This is not going well because of the implementation of the curriculum isn't appropriate to the students' needs. The writer found those problematic when they conducted the research in that vocational school.

For examples: 
1. We must be patient in facing pandemic

2. The doctor's patient is now already recovered from the disease

In the first setences, the word patient, which has the part of speech as an adjective qualifies pandemic which funtionate as a noun. Meanwhile in the second one, which funtionate as a noun stands by itself. Those words both in the first and the second sentences have different meaning which suitable with the context of the sentences.

From the explanation above, almost students are very confused in interpreting and using homogeneous vocab in ESP especially in English for medical . With these obstacles, the students can't say what they mean or can't understand what the proper meaning of the sentences above. It's means that understanding vocabulary is very important in mastering English language. It's supported by Astryanti \& Anwar (2016:41) cited in (Anwar \& Efransyah, 2018) stated that "vocabulary is needed to improve the four English skills; listening, speaking, reading, and writing". Those four skills needs a critical thinking. It is supported by Janicek (2006) cited in (Nurhajati, 2020) which stated that "Critical Thinking is the intellectually disciplined process of actively and skillfully conceptualizing, applying, synthesizing and evaluating". In the line with this, (Hinkel, 2018) stated that "Teaching learners to speak another language means helping develop specific sets of international and communication skill.

This problem makes the writer interested to conduct the classroom action research to improve the ability in mastering English language especially the one for specific purposes. Contextual Teaching and Learning (CTL) are aimed at building knowledge and skill in meaningful way by engaging students, real life or authentic context. By implementing in it, the students are expected to produce English better, since it emphasizes on student's productive skill.

Many studies on contextual teaching and learning (CTL) have been conducted to increase student's capability. First, Lynch \& Harnish (2003) states that CTL enabled teachers to manage, motivate, and ultimately teach students effectively. They also pointed out that the students engaged in their studies also rated CTL classes as more interesting and more engaging which then was effective to maintain the students' continued engagement in learning activities. The second, Brand (2003) reports that CTL can increase students' motivation to learn. Komariah (2016) in her research reveals that the students were actively involved during teaching and learning process that may result in increasing student. Further she says that CTL is appropriate for learners to increase their English. That's why this research was conducted to find out deficiencies, desire, and the needs of students in pharmaceutical field to propose accordingly teaching method recommendation for teaching English in the pharmacy study program. This study aims to determine the effectiveness level of ability student in English.

\section{METHOD}

In this research, the writer used descriptive qualitative method. According to ospina (2004, cited in Kuswandi \& Apsari, 2019), descriptive qualitative research as from of systematic empirical inquiry into meaning. The writer was conducted to obtain data through classroom action research. Classroom action is a research methodological approach that consists of cyclical process initiated by the need to solve problem (Dick \& Swepson, 1997).

The research was conducted in a vocational school pharmacy program at the SMK Kesehatan Bakti Assyukur by providing test (pre-test and post-test) to find out their current level. There are 21 students at tenth grade. That are choosen by the researcher. The researchers took at three samples from the higher ability, three samples from middle and the three ones from the lowest. 


\section{RESULTS AND DISCUSSION}

\section{Results}

From the result of the research. The researchers had classified the data into, three types namely the first data is grade A categorized (high ability), the second data was grade B (medium ability) and the third data is grade C (low ability). Grade A are students who had score of more than 71, while grade B are students who got score greater than 55 until 70 and grade $\mathrm{C}$ are students who got score less than 54 .

Here are following the result of the pre-test:

Table 1

The score of Pre-test

\begin{tabular}{|c|c|c|c|c|c|c|c|}
\hline \multirow{2}{*}{$\mathrm{NO}$} & \multirow{2}{*}{ Population } & \multicolumn{5}{|c|}{ SCORE ASPECT } & \multirow{2}{*}{$\begin{array}{l}\text { Total } \\
\text { Score }\end{array}$} \\
\hline & & Pronouncation & Grammar & Vocabulary & Fluency & Comprehension & \\
\hline 1 & Student 1 & 12 & 16 & 12 & 16 & 16 & 72 \\
\hline 2 & Student 2 & 12 & 12 & 8 & 12 & 16 & 60 \\
\hline 3 & Student 3 & 12 & 12 & 8 & 12 & 12 & 56 \\
\hline 4 & Student 4 & 12 & 12 & 8 & 12 & 12 & 56 \\
\hline 5 & Student 5 & 8 & 12 & 8 & 12 & 12 & 52 \\
\hline 6 & Student 6 & 12 & 8 & 4 & 12 & 8 & 44 \\
\hline 7 & Student 7 & 8 & 8 & 4 & 12 & 12 & 44 \\
\hline 8 & Student 8 & 4 & 8 & 4 & 8 & 12 & 36 \\
\hline \multirow[t]{2}{*}{9} & Student 9 & 4 & 8 & 4 & 4 & 4 & 24 \\
\hline & & & & & & Mean & 49,3 \\
\hline
\end{tabular}

From the table above the rating scores of each aspect are 1-5 which was multiplied by 4 . To get a maximal scores each aspect has 20 point which multified by 5 become 100 for maximal score. From the scores of pre-tests showed that only one student had grade A (71), three students had a grade B and the other students got grad C (54).

After giving the treatment for about meeting. The writers conducted a post test. The results are as follow:

Table 2

The score of Post-test

\begin{tabular}{|c|c|c|c|c|c|c|c|}
\hline \multirow[b]{2}{*}{ NO } & \multirow[b]{2}{*}{ Population } & \multicolumn{5}{|c|}{ SCORE ASPECT } & \multirow[b]{2}{*}{ Total Score } \\
\hline & & $\begin{array}{l}\text { Pronou- } \\
\text { ncation }\end{array}$ & $\begin{array}{l}\text { Gram- } \\
\text { mar }\end{array}$ & $\begin{array}{l}\text { Voca- } \\
\text { bulary }\end{array}$ & $\begin{array}{l}\text { Flue- } \\
\text { ncy }\end{array}$ & $\begin{array}{l}\text { Compre- } \\
\text { hension }\end{array}$ & \\
\hline 1 & Student 1 & 12 & 8 & 12 & 12 & 12 & 56 \\
\hline 2 & Student 2 & 12 & 16 & 16 & 16 & 16 & 72 \\
\hline 3 & Student 3 & 12 & 20 & 16 & 16 & 16 & 80 \\
\hline 4 & Student 4 & 16 & 16 & 16 & 16 & 16 & 80 \\
\hline 5 & Student 5 & 16 & 20 & 16 & 16 & 16 & 84 \\
\hline 6 & Student 6 & 16 & 16 & 12 & 12 & 12 & 68 \\
\hline 7 & Student 7 & 12 & 16 & 12 & 12 & 12 & 64 \\
\hline 8 & Student 8 & 20 & 16 & 20 & 16 & 16 & 88 \\
\hline \multirow[t]{2}{*}{9} & Student 9 & 12 & 12 & 8 & 12 & 8 & 52 \\
\hline & & & & & & averag & 71,56 \\
\hline
\end{tabular}


From the scores of post-test showed that after implementing the CTL, the students' score experienced positive changes. They are explained as follow:

It can be seen that the pre-test - post-test scored, average increases significantly. The result of the pre-test $49,3 \%$ and the post-test $71,5 \%$. But personally, some students both in grade A,B, and $\mathrm{C}$ had score inconsistenly. It was proven.

\section{Discussion}

After Collecting the data, the researcher analyzed the data as follow :

\section{Data 1 (hight ability)}

Student 1

\begin{tabular}{lcccccc}
\hline & Pronounciation & Grammar & Vocabulary & Fluency & comprehension & $\begin{array}{c}\text { Total } \\
\text { score }\end{array}$ \\
\hline pretest & 12 & 16 & 12 & 12 & 16 & 72 \\
\hline Post test & 12 & 8 & 12 & 12 & 12 & 56 \\
\hline
\end{tabular}

From the pretest showed that the first student had the highest score. But on the post-test it got 56. This phenomenon was not cause by academic ability. It is influenced by class attendance. So the first students didn't do the exam maximaly.

Student 4

\begin{tabular}{lcccccc}
\hline & Pronounciation & Grammar & Vocabulary & Fluency & comprehension & $\begin{array}{c}\text { Total } \\
\text { score }\end{array}$ \\
\hline pretest & 12 & 12 & 8 & 12 & 12 & 56 \\
\hline Post test & 16 & 16 & 16 & 16 & 16 & 80 \\
\hline
\end{tabular}

Different from student one. The pre-test and post-test scored experienced significantly. He experienced a significant increase. It was proven in all aspects and he had an almost perfect score especially in the vocabulary aspect from 8 at the pre-test score and 16 in the post-test. That is because the student four was always enthusiastic about learning method and being active students in the classroom.

\section{Data 2 (medium ability)}

Student 7

\begin{tabular}{lcccccc} 
& Pronounciation & Grammar & Vocabulary & Fluency & comprehension & $\begin{array}{c}\text { Total } \\
\text { score }\end{array}$ \\
\hline pretest & 8 & 8 & 4 & 12 & 12 & 44 \\
\hline Post test & 12 & 16 & 12 & 12 & 12 & 64 \\
\hline
\end{tabular}

From the pre-test and post-test of the data above. It showed that the progress of student seven experienced on medium position. It was proven in the score of the table, where three aspects increased significantly.

\section{Data 3 (low ability)}

Student 9

\begin{tabular}{lcccccc}
\hline & Pronounciation & Grammar & Vocabulary & Fluency & comprehension & $\begin{array}{c}\text { Total } \\
\text { score }\end{array}$ \\
\hline pretest & 4 & 8 & 4 & 4 & 4 & 24 \\
\hline Post test & 12 & 12 & 8 & 12 & 8 & 52 \\
\hline
\end{tabular}

From the pre-test and post-test of the data above. It showed that the progress of student nine. Experienced on the low position. It is shown by the pre-test score 24 and the post-test score 52. That the both of the tests, they were got classified on the grade $\mathrm{C}$. 


\section{CONCLUSION}

From the data above. It showed that the "Contextual Teaching and Learning Method" had given an effect of effectiveness in learning and understanding English Specific Purpose especially on homonymous vocabulary. It is proven from the pre-test scored with a total $49,3 \%$ increasing to $71,56 \%$. The improvement was shown before and after they were taught using this technique. From the student's improvement score, the researcher concluded that the "Contextual Teaching and Learning Method" was very effective in shaping the mindset of students in responding to subjects especially English lessons in vocational school and this method was one that could be used by teachers in achieving learning goals.

\section{ACKNOWLEDGMENTS}

Very big thanks to Allah SWT. I present to sincere appreciation for Mr. Efransyah, as lecturer, the researchers' guider, leader and role mode in the learning grammar English language. Thank you very much to SMK Kesehatan Bakti Assyukur who has let me to conduct the research in the school.

\section{REFERENCES}

Anwar, Y. T., Efransyah. (2018). Teaching English Vocabulary Using Crossword Puzzle Game At The Seventh Grade Students. Project (Professional Journal of English Education), 1(3), 235-240

Brand, B. (2003). Essential of High School Reform: New Forms of Assessment and Contextual Teaching and Learning. Washington: American Youth Policy Forum.

Dick, B and Swepson, P. (1997). Action Research FAQ: "frequently asked questions" file. Available at: http://www.scu.edu.au/schools/gem/ar/arp/arfaqhtm. Accessed on June 10th, 2020

Hinkel, E. (2018). Teaching speaking in integrated-skills classes. The TESOL Encyclopedia of English Language Teaching, 1-6 https://doi.org/10.1002/9781118784235.eelt0256

Hutchinson, T., Waters, A. (1992). English for Specific Purposes: A Learning-Centered Approach. Cambridge. Cambridge University press

Komariah, R., Subarjah, H., \& Sujana, A. (2016). Pengaruh Model Pembelajaran Contextual Teaching And Learning Terhadap Kemampuan Berpikir Kritis Siswa Pada Materi Energi Panas. Jurnal Pena Ilmiah, 1(1), 621-630. doi:https://doi.org/10.17509/jpi.v1i1.2993

Lynch, R.L., Harnish, D. (2003). Contextual Teaching and Learning: Lessons Learned from Teacher Preparation through Novice Teaching. Georgia. University of Georgia.

Nurhajati, D., Kencanawati, D., Riwayatiningsih, R. (2020). Enhancing Critical Thinking in Speaking Skill through Sekawan-P. English Education, Journal of English Teaching and Research, 5(1), 92-102

Simbolon, D.R.S., Haryudin, A., Efransyah. (2019). Improving Students' Speaking Skill Through Project Based Learning (Pbl). Project (Professional Journal of English Education), 2(2), 140-145

Sofiana, N., Mubarok, H., \& Yuliasri, I. (2019). English language teaching in secondary school: An analysis of the implementation of Indonesian ELT 2013 curriculum. Int Journal of Instruction, 12(1), 1533-1544. https://doi.org/10.29333/iji.2019.12198a 